\title{
SHORT COMMUNICATION Performance of local fowls fed plantain peels meal
}

C.T. Ezeokeke.

Department of Animal Science and Technol ogy, Federal University of Technology

Owerri. Nigeria.

Email:chycorn@yahoo.com

\begin{abstract}
Experiment was carried out to determine performance of day old local fowls, fed supplemented plantain peels meal (PPM). The birds were arranged in completely randomized design having six birds per replicate and two treatments comprising one test diet and one control diet. At starter phase, all the parameters (body weight, body weight gain, feed intake and feed conversion ratio) measured were not significant $(p>0.05)$. The birds on the test diet had average initial weight, $42.00 \mathrm{~g}$ while that of the control had average weight, $43.75 \mathrm{~g}$ and at 5 weeks of age average weights of $133.30 \mathrm{~g}$ and $134.54 \mathrm{~g}(p>0.05)$, respectively. At the finisher phase, all the parameters measured were not significant $(p>0.5)$. The prices per $\mathrm{kg}$ of feed for the test and control diets were N93.05 and N95.05, respectively. Therefore, PPM inclusion fed at early stage of life of the birds enhanced performance at a lower cost
\end{abstract}

Keywords: Performance, local fowls, plantain peels meal

\section{Introduction}

Local fowl is a native strain of domestic fowl. It has undergone the process of natural selection and inbreeding over time for its existence and multiplication in the respective environment it inhabits (Ezeokeke, 2003). In the past in Nigeria local fowl has been cross bred with imported strains in an exchange program that failed because the heritability index of the successive generation was very low and was lost entirely over time in the progeny (Oluyemi, 1979).

There is paucity of information on management and production of local birds. In poultry production feed takes about $70 \%$ of cost of production excluding cost of dayold commercial birds; currently at average cost of about N150 and N200 for broilers and pullets, respectively. The local fowls can be improved as table birds adopted as a means of bridging the protein gap currently at $5 \mathrm{~g}$ per day for an average adult in Nigeria as against $35 \mathrm{~g}$ recommended by FAO (1990). The birds will assume economic importance by serving as a cheaper source of animal protein to the teeming populace especially those living in the rural areas since the bulk of the holders of this stock are subsistent farmers residing in the rural areas (Ezeokeke et al., 2010).

PPM is a nonconventional feed resource to poultry. The proximate fractions of PPM according to Ketiku (1979) are Dry matter 87.58 , crude protein 5.73 , crude fibre 5.06, ether extract 2.06, ash 5.62 and NFE $70.30 \%$. Its use in local birds' nutrition is yet to be widely applied in intensive production of the birds. Tewe (1983) worked extensively on PPM fed broilers. He came out with result on performance that was favorable within the limits of 5$10 \%$ inclusion of PPM and the diets were 
Performance of lo cal fowls fed plantain peels meal

Table 1: Gross composition of experimental diets at starter and finisher phase

\begin{tabular}{lllll}
\hline & Starter diet & & Finisher diet & \\
\hline & Control & Test & Control & Test \\
\hline Maize & 46.96 & 39.54 & 57.05 & 49.53 \\
Groundnut cake & 36.93 & 37.99 & 26.84 & 28.00 \\
Wheat offals & 5.00 & 5.00 & 5.00 & 5.00 \\
Fish meal & 2.00 & 2.00 & 2.00 & 2.00 \\
Bone meal & 3.00 & 3.00 & 3.00 & 3.00 \\
Oyster shell & 2.00 & 2.00 & 2.00 & 2.00 \\
Lysine & 1.25 & 1.25 & 1.25 & 1.25 \\
Methionine & 0.86 & 0.86 & 0.86 & 0.86 \\
Common salt & 1.00 & 1.00 & 1.00 & 1.00 \\
Premix & 1.00 & 1.00 & 1.00 & 1.00 \\
Plantain peel meal & 0.00 & 6.36 & 0.00 & 6.36 \\
\hline Total & 100.00 & 100.00 & 100.00 & 100.00 \\
\hline Calculated & & & & 20 \\
analysis & & 23 & & 3000 \\
Crude protein\% & & 2800 & &
\end{tabular}

Energy

( $\mathrm{kcalME} / \mathrm{kg})$

*Premix produced the following per $\mathrm{kg}$ of feed:

Vitamin , 8,000,000 IU, vitamin $\mathrm{D}_{3}$ 1,600,000 IU, vitamin E 5,000 IU, vitamin $\mathrm{K}, 2,000 \mathrm{mg}$, thiamin $\left(B_{1}\right), 1,500 \mathrm{mg}$, riboflavin $\left(B_{2}\right), 4,000 \mathrm{mg}$, pyridoxine $\left(B_{6}\right), 1,500 \mathrm{mg}$, niacin, 15,500mg, vitamin $\mathrm{B}_{12}, 10 \mathrm{mg}$, pantothenic acid, 5,000mg,folic acid, 500mg ,biotin, 20mg, choline chloride, $200 \mathrm{~g}$, antioxidant, $125 \mathrm{~g}$, manganese, $80 \mathrm{~g}$, zinc $50 \mathrm{mg}$, iron, $20 \mathrm{~g}$, copper, $5 \mathrm{~g}$, iodine $1.2 \mathrm{~g}$, selenium, $200 \mathrm{mg}$, cobalt, $200 \mathrm{mg}$.

cost effective.

The study replaced maize with PPM at 6\% level of inclusion of the diets. The diets were fed to indigenous chickens at starter (0-4wks) and finisher (5-8wks) phases. This was done in order to achieve enhanced performance of the birds. The success of the trial could be assessed from the test diets achieving the same level of performance at a relatively cheaper cost of the diet with the controls.

\section{Materials and methods}

The study was carried out at the Teaching and Research Farm of Federal University of Technology Owerri. Owerri is in the tropical rain forest region of the south east of Nigeria.

The eggs were selected from rural communities where no cross breeding of the fowls with the imported ones have occurred. Eggs were purchased from the rural outlets for local eggs and hatched to obtain the day old indigenous chicks that were used for the experiment. The eggs were white in color, small and weighed averagely $45.35 \mathrm{~g}$ per egg. One hundred and twenty eggs were candled, out of which $35 \%$ hatched into day-old chicks. Thirty-six day-old unsexed indigenous chicks were used for the study. Two treatments with three replicates per treatment and six birds per replicate distributed in completely randomized design were employed. The gross composition of experimental diets is as shown in Table 1. Test diet had 6\% inclusion of PPM at starter and finisher phases.

The birds received medicare and strict 
management practice was adhered to at respective stages. Intraocular vaccine at day old, New castle disease vaccine at one week old, Gumboro vaccine at 2 wks followed repeatedly at $3^{\text {rd }}$ and $4^{\text {th }}$ wks, coccidiostat and deworming at $4^{\text {th }}$ wks were administered to the birds. The birds were kept under intensive system of management. The experiment lasted for eight weeks.

The data collected were subjected to analysis of variance and mean separation was done by t-test and least significant difference methods as adopted by Njoku $e t$ al. (1998).

\section{Results and discussion}

The results of the experiment are as shown in Tables 2.

At the starter and finisher phases all the parameters measured were not significant $(\mathrm{p}>0.05)$. Results compared favorably with that reported on broilers by Tewe (1983). But the average initial weight of the test birds was $42.00 \mathrm{~g}$ and at 5 weeks (starter phase) attained $133.30 \mathrm{~g}$ and body weight gain/day of $25.33 \mathrm{~g}$. These happened at the early stages of growth of the fowl. This potential can be utilized in the improvement of the local birds as table birds. The birds had the capacity to put on weight easily especially when fed with plantain peels meal at the early stages of life. At the finisher phase or over prolong periods of feeding of plantain peels meal to local fowls caution is to be taken because it has a negative effect on performance judging from the diminishing results obtained in this period from the present study.

The birds on test diets had no significant enhanced performance over those of control. However, they achieved the same level of performance $(p>0.05)$ with the control at a cheaper cost. In economy of scale this could be exploited to boost profit in commercial poultry enterprise.

\section{Conclusion}

Experiment was conducted to determine performance of indigenous domestic birds

Table 2: Performance of local birds on experimental diets at the starter phase and finisher phase

Performance of local birds on experimental diets at the starter phase

\begin{tabular}{lccc}
\hline & \multicolumn{2}{c}{ Experim ent diets } & \\
& Control & Test & SEM \\
\hline Initial body wt/ bird (g) & 43.75 & 42.00 & 1.23 \\
Average body wt/bird at 5wks (g) & 134.54 & 133.30 & 24.43 \\
Average body wt gain/bird/wk (g) & 22.70 & 25.33 & 10.91 \\
Average feed intake/bird/day (g) & 16.88 & 22.47 & 3.95 \\
Average feed conversion ratio/bird & 5.20 & 6.21 & 0.71 \\
\end{tabular}

Performance of local birds on experimental diets at the finisher phase

\begin{tabular}{lccc}
\hline \multicolumn{4}{c}{ Experim ent diets } \\
\\
\hline Average body wt/bird at 10wks (g) & Control & Test & SEM \\
Average body wt gain/bird/wk (g) & 423.00 & 341.70 & 66.82 \\
Average feed intake/bird/day (g) & 57.19 & 34.60 & 15.97 \\
Average feed conversion ratio/bird & 35.05 & 29.52 & 3.91 \\
& 3.21 & 4.64 & 1.01 \\
\hline
\end{tabular}


of Owerri ecotype fed plantain peels meal at starter and finisher phases. Plantain peels meal at $6 \%$ level of inclusion was useful as cost effective ingredient in the diets of local birds in an experiment that lasted for 8 weeks. Therefore, PPM can be used in profitable poultry production.

\section{References}

Ezeokeke, C.T. 2003. Studies on the requirement for energy, protein and feed additives by the local fowl. PhD Thesis.University of Ibadan, Ibadan, Nigeria.

Ezeokeke, C.T., Okoili, I.C, Durunna, C.S., Uchegbu, M.C., Obikaonu, H.O andOkoro, V.M. 2010. Farmers' profile, local fowl and their egg quality in six local government areas of Imo state. Nigerian Poultry Science Journal 6:57-64.
Food and Agriculture Organisation (FAO) 1990. Bulletin of Food and Agriculture Rome.

Ketiku, A. (1979). In: Tewe 1983. Replacing maize with plantain peels meal in diet for broilers. Nutrition Reports International 28: 1, 23-29.

Njoku, D.C., Onuh, M.O. and Ohazurike, N.C. 1998. Research Method and Field Experimentation in Agriculture and Biological Sciences. Alphabet publisher Nigeria.

Oluyemi, J.A. 1979. Potentialities of the indigenous species of poultry for meat and egg productions. Nigerian Society for Animal Production Conference held at ABU, Zaria, December 11-13 ${ }^{\text {th }}$.

Tewe,O.O.1983. Replacing maize with plantain peels in diets for broilers. Nutrition Report International 28(1):23-29.

Received: $15^{\text {th }}$ March, 2011 Accepted: $2^{\text {nd }}$ August, 2012 